12. Hu MTM, Taylor-Robinson SD, Chaudhuri KR, et al. Evidence for cortical dysfunction in clinically non-demented patients with Parkinson's disease: a proton MR spectroscopy study. J Neurol Neurosurg Psychiatry 1999;67:20-26.

13. American Psychiatric Association. Diagnostic and statistical manual of mental disorders, 4th rev. ed. Washington, D.C.: American Psychiatric Association, 1994.

14. Spinks TJ, Bailey DL, Bloomfield PM, et al. Performance of a new 3D-only PET scanner: the Exact 3d. IEEE Nuclear Science Symposium and Medical Imaging Conference, Anaheim, CA, 1996:1275-1279.

15. Hu MTM, Taylor-Robinson SD, Chaudhuri KR, et al. Cortical dysfunction in non-demented Parkinson's disease patients. A combined ${ }^{31} \mathrm{P}-\mathrm{MRS}$ and ${ }^{18}$ FDG-PET study. Brain 2000;123: $340-352$.
16. Woods RP, Mazziotta JC, Cherry SR. MRI-PET registration with automated algorithm. J Comput Assist Tomogr 1993;17:536-546.

17. Patlak CS, Blasberg RG. Graphical evaluation of blood-tobrain transfer constants from multiple-time uptake data. Generalizations. J Cereb Blood Flow Metab 1985;5:584-590.

18. Brooks DJ, Salmon EP, Mathias CJ, et al. The relationship between locomotor disability, autonomic dysfunction, and the integrity of the striatal dopaminergic system in patients with multiple system atrophy, pure autonomic failure, and Parkinson's disease, studied with PET. Brain 1990;113:1539-1552.

19. Burn DJ, Sawle GV, Brooks DJ. Differential diagnosis of Parkinson's disease, multiple system atrophy, and Steele-Richardson-Olszewski syndrome: discriminant analysis of striatal ${ }^{18} \mathrm{~F}$-dopa PET data. J Neurol Neurosurg Psychiatry 1994;57:278-84.

\title{
Neuro/mages
}
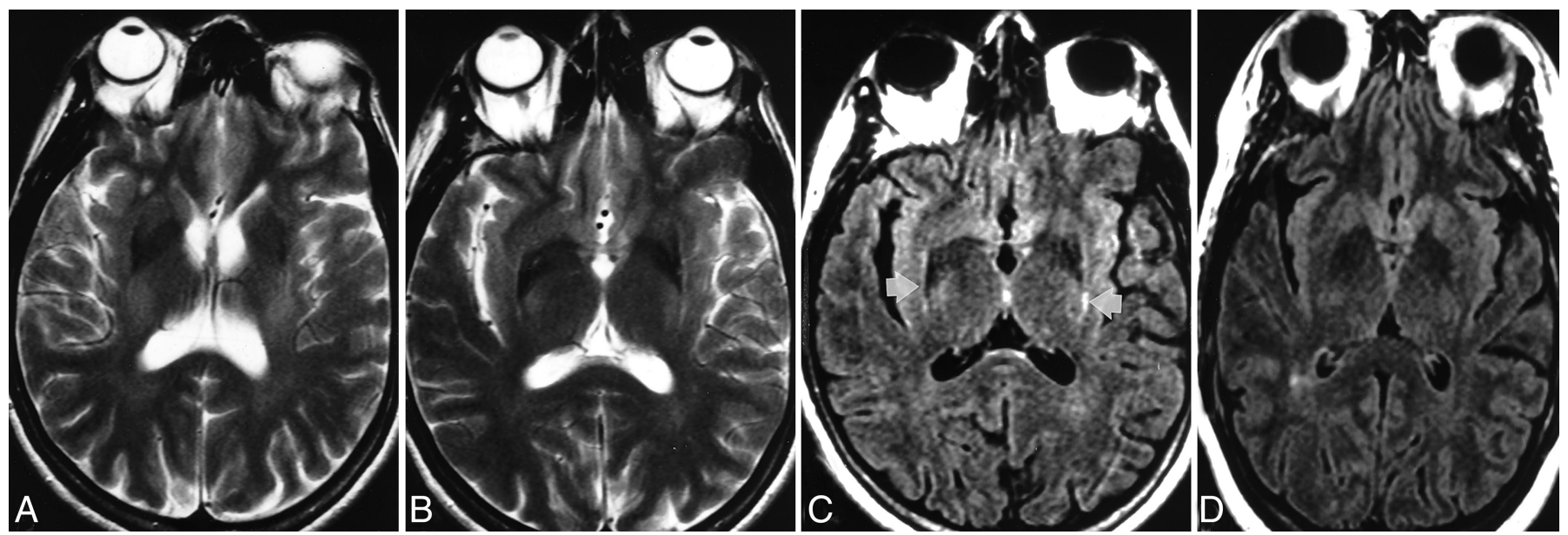

Figure. Axial T2 (A-B) and fluid attenuated inversion recovery (FLAIR) (C-D) MRI, performed as detailed. ${ }^{2}$ The patient (A-C) has posterior/lateral putamen hypointensity (iron deposition) (A-B). The patient's FLAIR $(C)$ shows linear lateral putamen hyperintensities (arrows), seen better on FLAIR than on T2 (B). Such hyperintensities are absent on FLAIR from an age-matched, healthy control (D).

\section{FLAIR MRI of striatonigral degeneration}

\section{Sandra A. Block, MD, Rohit Bakshi, MD, Buffalo, NY}

A 43-year-old woman had cogwheel rigidity, bradykinesia, bowel/bladder retention, and tongue tremor (levodopanonresponsive). Brisk deep tendon reflexes and extensor plantar responses were noted. MRI is shown (figure). SPECT showed striatal hypoperfusion. Multiple system atrophy/ striatonigral degeneration (MSA/SND) was diagnosed.

The combination of linear T2 hyperintense putamenal rims and medial putamenal hypointensity suggests MSA/ SND. ${ }^{1}$ FLAIR uses CSF suppression and strong T2 weight- ing, producing better lesion/tissue contrast than standard T2 images in the brain. ${ }^{2}$ Our case shows the better depiction of hyperintense rims on FLAIR as compared with T2 images in MSA/SND, suggesting that FLAIR is useful in the evaluation of atypical parkinsonism.

1. Kraft E, Schwarz J, Trenkwalder C, et al. The combination of hypointense and hyperintense signal changes on T2-weighted magnetic resonance imaging sequences: a specific marker of multiple system atrophy? Arch Neurol 1999;56:225-228.

2. Bakshi R, Ariyaratana S, Benedict RHB, Jacobs L. Fluid-attenuated inversion-recovery MRI detects cortical and juxtacortical multiple sclerosis lesions. Arch Neurol 2001 (in press). 


\title{
Neurology
}

\author{
FLAIR MRI of striatonigral degeneration \\ Sandra A. Block and Rohit Bakshi \\ Neurology 2001;56;1200 \\ DOI 10.1212/WNL.56.9.1200
}

This information is current as of May 8, 2001

\section{Updated Information \&} Services

References

Citations

Permissions \& Licensing

Reprints including high resolution figures, can be found at: http://n.neurology.org/content/56/9/1200.full

This article cites 1 articles, 0 of which you can access for free at: http://n.neurology.org/content/56/9/1200.full\#ref-list-1

This article has been cited by 1 HighWire-hosted articles: http://n.neurology.org/content/56/9/1200.full\#\#otherarticles

Information about reproducing this article in parts (figures,tables) or in its entirety can be found online at:

http://www.neurology.org/about/about_the_journal\#permissions

Information about ordering reprints can be found online:

http://n.neurology.org/subscribers/advertise

Neurology ${ }^{\circledR}$ is the official journal of the American Academy of Neurology. Published continuously since 1951, it is now a weekly with 48 issues per year. Copyright . All rights reserved. Print ISSN: 0028-3878. Online ISSN: 1526-632X.

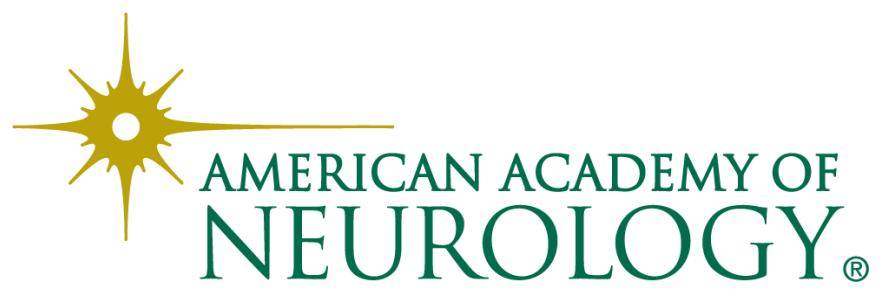

